The East African Medical Journal Vol. 81 No. 1 January 2004

CHANGES IN BLOOD LEVELS OF EOSINOPHIL CATIONIC PROTEIN AND TRYPTASE AFTER EXERCISE CHALLENGE IN ADOLESCENTS WITH EXERCISE-INDUCED ASTHMA

B. O. Onadeko, MD(Dublin) FRCP(Lond), Professor of Medicine, Kuwait University, Kuwait, M. E. Khadadah, MB, FRCP(Lond), Associate Professor of Medicine, Kuwait University, Kuwait, C. I. Ezeamnzie, Ph.D (Lond), Immunopharmacology unit, Department of Pharmacology, Kuwait University, Kuwait, R. Marouf, MB, FRCPath. Assistant Professor, Department of Pathology (Hacmatology unit), Kuwait University, Kuwait, M. Zubaid, MB, FRCPC, Associate Professor/ Cardiologist, Department of Medicine, Kuwait University, Kuwait, N. Maradni, MD, Chest Physician, Mubarak Al-Kabir Hospital, Kuwait, B. Jayakrishnan, MD, Chest Physician, Mubarak Al-Kabir Hospital, Kuwait, A. Memon, MB, D.Phil (Oxon) Department of Community Medicine, Statistics unit, Kuwait University, Kuwait

Request for reprints to: Dr. B. O. Onadeko, Department of Medicine, Faculty of Medicine, Kuwait University, P. O. Box 24923, Safat 13110, Kuwait or Dr. B. O. Onadeko, P. O. Box 29279, Secretariat Post office, Ibadan, Oyo state, Nigeria

\title{
CHANGES IN BLOOD LEVELS OF EOSINOPHIL CATIONIC PROTEIN AND TRYPTASE AFTER EXERCISE CHALLENGE IN ADOLESCENTS WITH EXERCISE-INDUCED ASTHMA
}

\author{
B. O. ONADEKO, M. E. KHADADAH, C. I. EZEAMNZIE, R. MAROUF, M. ZUBAID, N. MARADNI,
} B. JAYAKRISHNAN and A. MEMON

\begin{abstract}
Background: Exercise-induced asthma (EIA) is increasingly encountered among school children in Kuwait. Available evidence has shown that inflammatory mediators may be involved in the pathogenesis of EIA. Studies on release of inflammatory mediators have been carried out in adult patients with asthma in Kuwait, but no study on EIA involving children has taken place in this region.

Objective: To investigate changes in the concentration of some of the mediators involved in EIA in adolescent school children, Using exercise challenge.

Design: Prospective, case control study.

Setting: Respiratory and Cardiology units Mubarak Hospital, Kuwait, between January and June 2001.

Subjects: Nine EIA and 14 non-EIA and 10 normal control subjects, designated as groups one, two and three aged between 13 and 17 years, who were non-smokers, were enrolled for the study

Main Outcome Measures: Blood eosinophils (EOS), eosinophil cationic protein (ECP) and tryptase were estimated pre-exercise, 5 and 30 minutes after exercise. Spirometry was measured at the same period.

Results: In group one, ECP and tryptase levels fell after exercise, but significant difference in the levels were obtained only in tryptase between pre-exercise and 30 minutes after exercise. $(4.1 \mu \mathrm{g} / \mathrm{L} \mathrm{Vs} 3.8 \mu \mathrm{g} / \mathrm{L}) \mathrm{P}<0.05$, while the difference for $\mathrm{ECP}$ was not significant $(P=0.09)$. In group two, both tryptase $(6.0 \mu \mathrm{g} / \mathrm{L} \mathrm{Vs} 5.7 \mu \mathrm{g} / \mathrm{L}) \mathbf{P}$ $<0.05$, and ECP $(21.8 \mu \mathrm{g} / \mathrm{L}$ Vs $12.1 \mu \mathrm{g} / \mathrm{L}) \quad \mathrm{P}<0.01$, fell after exercise.

However, in group three, no appreciable difference was observed between pre and post exercise. Correlation between tryptase and $\operatorname{EOS}(r=0.770 ; P<0.05)$ and between tryptase and $\operatorname{ECP}(r=0.850 ; p<0.05)$ was observed pre-exercise and after exercise in groups one and two.

Conclusion: A fall in the level of the mediators was observed after exercise challenge, but the relevance of this finding in the pathogenesis of EIA remains unclear. Further studies are required to verify this finding.
\end{abstract}

\section{INTRODUCTION}

Exercise-induced asthma (EIA) occurs in 70 to $80 \%$ of asthmatics, most commonly among those with moderate to severe airway hyperresponsiveness(1). EIA is defined as transient airflow obstruction greater than $15 \%$ decrease in forced expiratory volume in one second $\left(\mathrm{FEV}_{\mathrm{I}}\right)$ following five to eight minutes of exercise(2). Proposed mechanisms for broncho constriction include, mucosal drying and increased osmolality stimulating mast cell degranulation; rapid airway rewarming after exercise, causing vascular congestion, increased permeability and oedema leading to obstruction(3).

Previous indications for participating mast cell mediators in the pathogenesis of EIA are based on pharmacological data, for example, that disodium cromoglycate, a drug which stabilizes mast cell membrane, B-2-agonist, and calcium antagonist are effective in blocking exercise induced asthma(4-7). The direct approach of measuring mast cell mediator release in response to exercise challenge has yielded conflicting 
results. While some studies reported elevation in plasma and whole blood histamine concentrations $(8,9)$, others cannot confirm this finding $(10,11)$.

Increases in the levels of tryptase and prostaglandin $\left(\mathrm{PGD}_{2}\right)$ both specific mast cell markers, have been detected in nasal lavage following nasal provocation with cold dry air(12), but not after exercise $(13,14)$. Further evidence for mast cell activation during exerciseinduced bronchospasm has also been provided in the study of O'Sullivan and colleagues(15). They concluded from their study that the findings of increased urinary levels of $\mathrm{p} \alpha$ and $11 \beta$ prostaglandin $\mathrm{F}_{2}$ provide strong evidence for mast cell activation during exercise induced bronchospasm. With the concept of airway inflammation, the involvement of eosinophils (EOS) in asthma has been a focus of attention in the last two to three decades. Increases in eosinophil numbers and eosinophil degranulation products, such as eosinophil cationic protein (ECP) and major basic protein (MBP) in peripheral blood as well as in bronchoalveolar lavage fluid in patients with a late asthmatic response (LAR) have been reported $(16,17)$. Elevation of both EOS and ECP levels during exercise has been reported(18-21). Venge et al.(18) found elevation of both EOS and ECP levels during exercise in blood of adult asthmatics and they suggested that a relationship might exist between the severity of EIA and serum ECP. On the other hand, recently, Gauvreau and colleagues(22) reported that there was no significant change in eosinophil inflammation in EIA.

The prevalence of asthma is increasing in Kuwait, presumably due to increasing industrialisation and improvement in the socio-economic life in the community. Studies on mediator release in subjects with asthma have been previously reported in this environment(23,24). Since EIA is also reasonably encountered, especially among school children in our practice, we decided to investigate the pattern of mediator release in subjects with this condition, by evaluating changes which may occur in the levels of tryptase and eosinophils and its product, ECP after exercise challenge.

\section{MATERIALS AND METHODS}

This study was conducted at the chest unit of Mubarak Hospital, a tertiary medical center in Kuwait, between January and June 2001.

Two groups of adolescent school children, diagnosed as cases of asthma, who were non smokers, aged between 13 and 17 years were enrolled for the study. Group one consisted of nine subjects who had previously been confirmed to have exercise-induced asthma (EIA) at the Department of Physiology, Kuwait University, after a 6-8 minutes of exercise on threadmill resulted in $\geq 15 \%$ decrease in FEV 1 . Group two consisted of 14 subjects, who were confirmed by pulmonary function test, as asthmatics, among the patients attending the chest clinic. The subjects in this group had negative response to exercise challenge test, and were designated as non-EIA.
The subjects in groups one and two were on regular maintenance therapy of inhaled salbutamol $600 \mu \mathrm{g}$ daily and inhaled beclomethasone dipropionate 450 to $600 \mu \mathrm{g}$ daily, routinely used for mild asthmatics in Kuwait, before they were selected for the study. Inhaled corticosteroids were discontinued four weeks before the study. Subjects who could not tolerate withdrawal of corticosteroids were excluded from the final analysis. All other medications were however, discontinued the night before the exercise test.

Group three subjects consisted of non-smoking, healthy school children, matched for age, who had no previous history of asthma or any other cardiopulmonary disease. They served as controls. The parents of the subjects gave written consent for the study.

Exclusion criteria include history of exacerbation of symptoms in the last three months prior to the study, history of administration of oral corticosterioids in the last twelve months, and evidence of co-existing respiratory tract infection. Three subjects who could not tolerate withdrawal of corticosteroids during the study period or who could not successfully perform the pulmonary function test were also excluded.

The protocol used for the study contained information on history of the subjects' disease, triggers, previous and current drug used and dosage, history of exacerbation and family history. All subjects had physical examination.

Baseline/pre-exercise evaluation of total blood eosinophil count, serum ECP and tryptase was done. Spirometry (forced vital capacity (FVC), forced expiratory volume in one second $\left(F_{\mathrm{I}}\right)$ and peak expiratory flow rate (PEF) was carried out also on all the subjects. This was perfomed by one technician, with the subjects in sitting position, according to the American Thoracic Society (ATS) criteria(25), using a portable vitalograph escort. (Vitalograph Ltd, Maidsmoretom House, Buckingham, MK 18, $1 \mathrm{SW}$, England). The highest of the three readings was recorded.

Exercise Challenge Test: This was performed using the ATS guidelines for exercise challenge test $(26)$. The procedure was explained to the subjects. Each subject was connected to the electrocardiographic monitor for measurement of heart rate. The test was performed, in the morning in an air conditioned room with ambient temperature of $20-25^{\circ} \mathrm{C}$, and low humidity, by one cardiologist, for all the subjects, assisted by a nurse who had experience with this procedure. A motordriven threadmill was used for the exercise test. The speed was adjusted progressively during the first two to three minutes of exercise until the heart rate reached $80-90 \%$ maximum capacity of the subject. The duration of the exercise was six minutes. Vital signs were monitored throughout the procedure. The subjects were asked to indicate if they felt uncomfortable or distressed during the procedure, the test being discontinued in such cases. Total EOS, serum ECP, and tryptase and spirometry were repeated at 5 and 30 minutes after the exercise.

Tryptase and ECP Analysis: Blood for ECP and tryptase was drawn in vacutainers SST-tubes (Becton, Dickenson, Franklin, Lakes N.J; USA) and allowed to clot for one to two hours. After centrifugation for ten minutes at $600 \mathrm{~g}$, the serum was collected and stored at $-70^{\circ} \mathrm{C}$ until analysis. Samples were analysed in duplicate, using Pharmacia CAP and UNICAP systems (Pharmacia and Upjohn, Uppsala, Sweden) for ECP and tryptase respectively. This test is based on the principles of fluoroimmuno assay in which the monoclonal antibody against the analyte which has been 
immobilised on a rigid matrix is used to capture the analyte in serum. After washing, a secondary antibody labelled with enzymes is reacted with the captured analyte. The fluorescence developed on addition of enzyme substrate is a function of the amount of analyte which is then quantitated in relation to the standard curve generated. Values were considered elevated at $>20 \mu \mathrm{g} / \mathrm{L} \mathrm{f} \mu$ or ECP and $>13.5 \mu \mathrm{g} / \mathrm{L}$ for tryptase. Total eosinophil count was estimated using a Coulter counter, Gen S, as described by Dacie and Lewis(27).

Statistical Analysis: Data management and analysis were conducted using SPSS statistical programme. The Wilcoxin signed rank test was used to assess the difference between the medium of the three groups. The Spearman rank correlation coefficient was used to assess association between two continuous variables. A $\mathrm{p}$ value of $<0.05$ was considered as significant.

\section{RESULTS}

Seven subjects out of nine, in group one, 13 out of 14 in group two and nine out of ten in group three completed-the study. The mean age of the subjects in groups one, two and three was $15.29 \pm 1.38,14.85 \pm 1.46$ and $15.33 \pm 1.94$ years respectively. Table 1 and figure 1 show the distribution of the levels of tryptase, ECP, EOS and $\mathrm{FEV}_{1}$ pre-exercise, 5 and 30 minutes after exercise. In group one, (table 2 and figure 2), the level of tryptase fell between pre-exercise and 30 minutes after exercise, the median range being $4.1 \mu \mathrm{g} / \mathrm{L}(0.2-6.3)$ vs $3.8 \mu \mathrm{g} /$ $\mathrm{L}(2.2-5.9)(\mathrm{P}<0.05)$ and between 5 and 30 minutes of exercise, the range being $4.1 \mu \mathrm{g} / \mathrm{L}(22-6.5)$ vs $3.8 \mu \mathrm{g} /$ $\mathrm{L}(2.2-5.9)(\mathrm{P}<0.05)$. EOS level rose between preexercise, 5 and 30 minutes after, but the difference was not significant.

Table 1

Summary of blood levels of Tryptase, ECP and Eosinophils Before and after exercise in the three Groups

\begin{tabular}{|c|c|c|c|c|c|c|c|c|c|c|c|c|}
\hline \multirow[t]{2}{*}{ Group } & \multicolumn{4}{|c|}{$\begin{array}{c}\mathrm{A}(\text { Before Exercise }) \\
\text { Median }(2.5 \text { th- } 97.5 \text { th percentile }\end{array}$} & \multicolumn{4}{|c|}{$\begin{array}{l}\text { B(5 Minutes after exercise }) \\
\text { Median }\left(2.5^{\text {th }}-97.5^{\text {th }} \text { percentile }\right)\end{array}$} & \multicolumn{4}{|c|}{$\begin{array}{l}\text { C(30 Minutes after Exercise }) \\
\text { Median }\left(2.5^{\text {th }}-9.75^{\text {th }} \text { percentile }\right)\end{array}$} \\
\hline & Tryp E & $\mathrm{ECP}$ & EOS & $\mathrm{FEV}_{1}$ & Tryp & ECP & EOS & $\mathrm{FEV}_{1}$ & Tryp & $\mathrm{ECP}$ & EOS & $\mathrm{FEV}_{1}$ \\
\hline I & $\begin{array}{l}4.1 \\
(0.2-6.3)\end{array}$ & $\begin{array}{l}18 \\
(4.1-93.8)\end{array}$ & $\begin{array}{l}0.1 \\
(0.0-0.5\end{array}$ & $\begin{array}{l}2.2 \\
(1.9-2.4)\end{array}$ & $\begin{array}{l}4.1 \\
(2.2-6.5)\end{array}$ & $\begin{array}{l}18.9 \\
(2.3-59.7)\end{array}$ & $\begin{array}{l}0.2 \\
(0.1-0.4)\end{array}$ & $\begin{array}{l}2.1 \\
(1.4-2.4)\end{array}$ & $\begin{array}{l}3.8 \\
(2.2-5.9)\end{array}$ & $\begin{array}{l}17.4 \\
(2.0-35.9)\end{array}$ & $\begin{array}{l}0.2 \\
(0.0-0.3)\end{array}$ & $\begin{array}{l}2.1 \\
(1.8-3.3)\end{array}$ \\
\hline II & $\begin{array}{l}6.0 \\
(1.3-10.1)\end{array}$ & $\begin{array}{l}21.8 \\
(6.2-62.0\end{array}$ & $\begin{array}{l}0.4 \\
(0.1-0.7\end{array}$ & $\begin{array}{l}1.9 \\
(1.4-2.9)\end{array}$ & $\begin{array}{l}5.9 \\
(1.9-10.7)\end{array}$ & $\begin{array}{l}14.6 \\
(3.7-51.7)\end{array}$ & $\begin{array}{l}0.4 \\
0.1-0.7)\end{array}$ & $\begin{array}{l}1.7 \\
(0.2-2.9)\end{array}$ & $\begin{array}{l}5.7 \\
(1.7-9.47)\end{array}$ & $\begin{array}{l}12.1 \\
(2.2-28.4)\end{array}$ & $\begin{array}{l}0.4 \\
(0.1-0.5)\end{array}$ & $\begin{array}{l}1.8 \\
(1.4-2.8)\end{array}$ \\
\hline III & $\begin{array}{l}4.3 \\
(3.4-7.2)\end{array}$ & $\begin{array}{l}19.5 \\
(6.0-27.5)\end{array}$ & $\begin{array}{l}0.1 \\
(0.1-27 .\end{array}$ & $\begin{array}{l}3.2 \\
.5)(2.4-4.1\end{array}$ & $\begin{array}{l}4.9 \\
(2.8-8.5)\end{array}$ & $\begin{array}{l}15.4 \\
(4.6-23.3)\end{array}$ & $\begin{array}{l}0.1 \\
(0.1-0.3)\end{array}$ & $\begin{array}{l}3.3 \\
(2.3-4.2)\end{array}$ & $\begin{array}{l}4.9 \\
(2.8-8.4)\end{array}$ & $\begin{array}{l}15.1 \\
(4.8-19.9)\end{array}$ & $\begin{array}{l}0.1 \\
0.1-0.3)\end{array}$ & $\begin{array}{l}3.4 \\
(2.3-4.0)\end{array}$ \\
\hline
\end{tabular}

Group I= Asthma with EIA

Group II= Asthma without EIA Group III= Controls

EIA $=$ Exercise-induced asthma

Units: Tryptase (Tryp) mcg/L; ECP mcg/L; EOS x 109/L; FEV 1 , Litres/minute

Table 2

$P$ Values of Variables Within the Group Before and After Exercise

\begin{tabular}{|c|c|c|c|}
\hline \multicolumn{4}{|c|}{ i) Tryptase } \\
\hline Group & $A$ and $B$ & $\mathrm{~A}$ and $\mathrm{C}$ & $\mathrm{B}$ and $\mathrm{C}$ \\
\hline 1 & 0.553 & $0.034 *$ & $0.028 *$ \\
\hline 2 & 0.753 & 0.084 & $0.021 *$ \\
\hline 3 & 0.767 & 0.767 & 0.953 \\
\hline \multicolumn{4}{|c|}{ ii) $\mathrm{ECP}$} \\
\hline Group & $\mathrm{A}$ and $\mathrm{B}$ & $\mathrm{A}$ and $\mathrm{C}$ & $\mathrm{B}$ and $\mathrm{C}$ \\
\hline 1 & 1.00 & 0.09 & 0.398 \\
\hline 2 & 0.087 & $0.010 * *$ & 0.108 \\
\hline 3 & 0.173 & 0.066 & 0.767 \\
\hline \multicolumn{4}{|c|}{ iii) Eosinophils } \\
\hline Group & $A$ and $B$ & $\mathrm{~A}$ and $\mathrm{C}$ & $\mathrm{B}$ and $\mathrm{C}$ \\
\hline 1 & 0.564 & 0.257 & 0.083 \\
\hline 2 & 0.705 & 0.059 & 0.063 \\
\hline 3 & 0.317 & 0.317 & 0.157 \\
\hline \multicolumn{4}{|c|}{ iv) FEV } \\
\hline Group & $\mathrm{A}$ and $\mathrm{B}$ & $\mathrm{A}$ and $\mathrm{C}$ & $\mathrm{B}$ and $\mathrm{C}$ \\
\hline 1 & 0.063 & 0.734 & 0.075 \\
\hline 2 & 0.099 & 0.625 & 0.638 \\
\hline 3 & 0.779 & 0.553 & 0.906 \\
\hline
\end{tabular}

$* \mathrm{P} \leq \mathrm{O} . \mathrm{O} 5 \quad * * \mathrm{P} \leq 0.01$

$\mathrm{P}$ values are based on Wilcoxon Signed Rank Test. Group $1=$ EIA, Group 2 = Non EIA, Group $3=$ Control $\mathrm{A}=$ Pre-exercise/ Baseline; $\mathrm{B}=5$ minutes after exercise; $\mathrm{C}=30$ minutes after exercise. $\mathrm{EIA}=$ Exercise-induced Asthma 
Figure 1a

Levels of trypase and eosinophil cationic protein (ECP) before and after exercise.

Group $1=E I A$

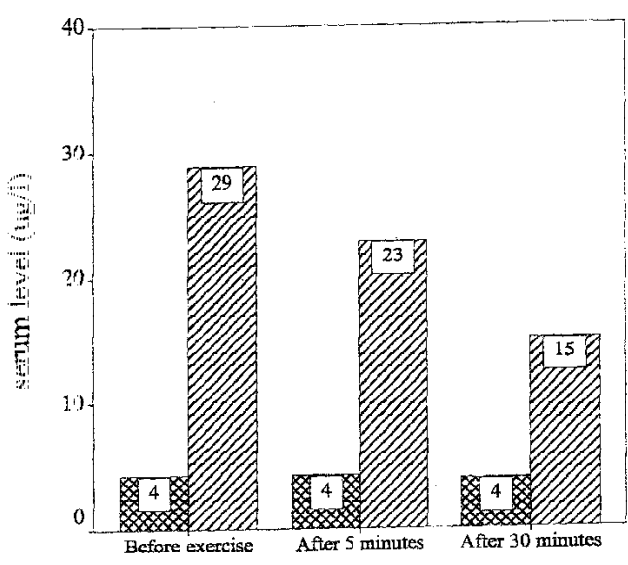

Tryptase DA्ACP

Group 2=Non-EIA

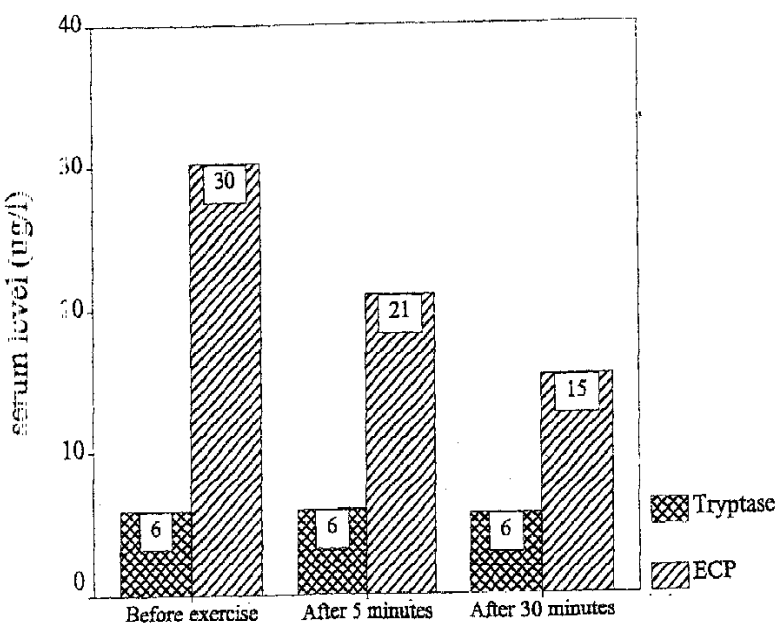

Figure 2a

Serum tryptase level before and after exercise in group 1

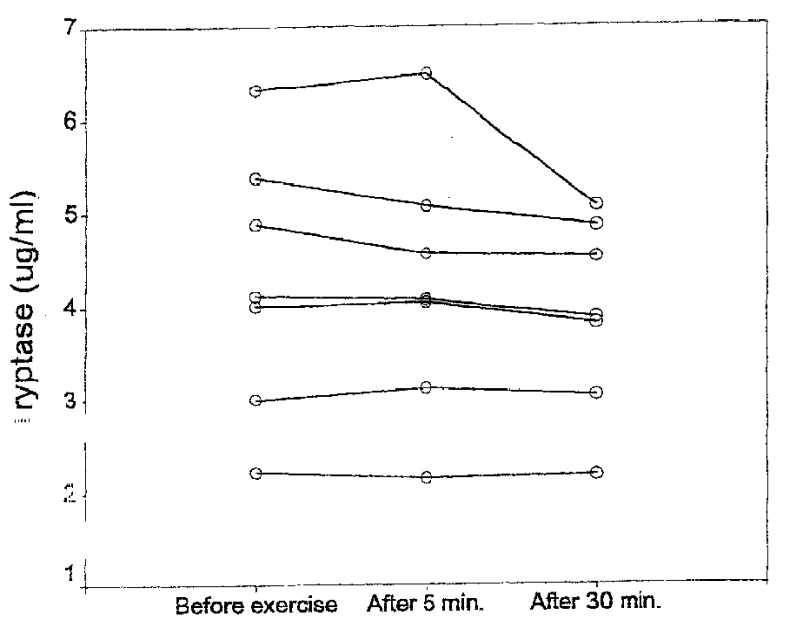

Figure 2b

Serum ECP level before and after exercise in group 1

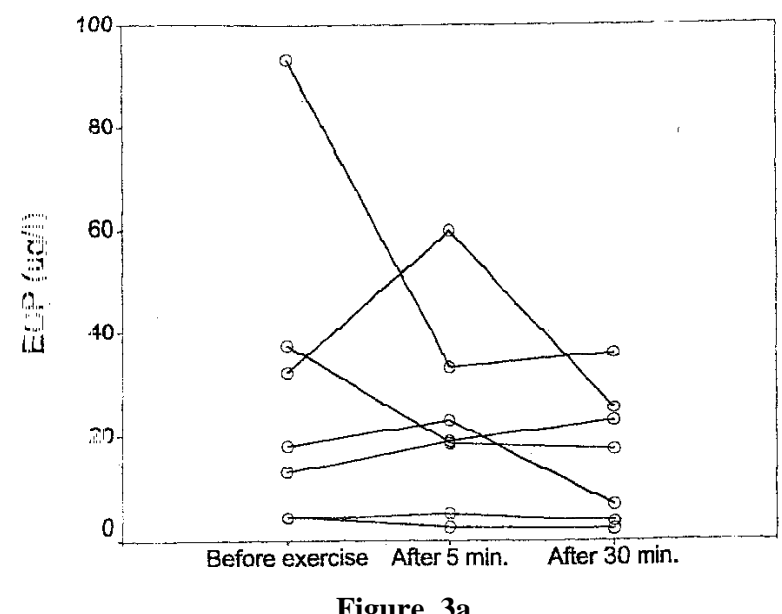

Serum tryptase level before and after exercise in group 2

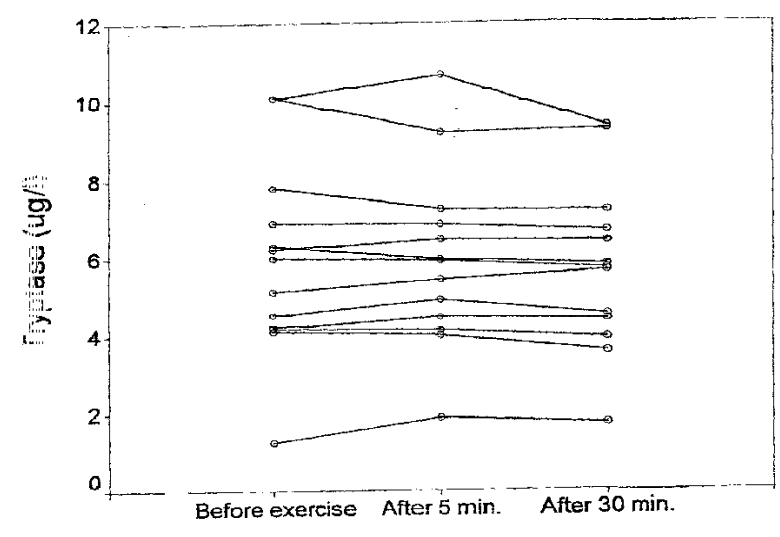

Figure 3b

Serum ECP level before and after exercise in group 2

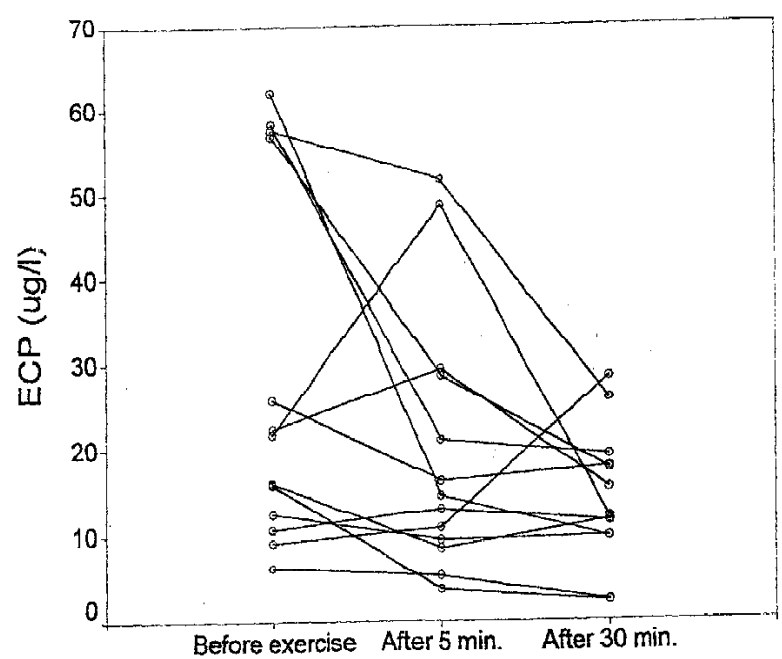


ECP level fell between pre-exercise and 30 minutes after, but the difference did not reach statistical significance $(\mathrm{P}=0.09)$.

In group two, (Table 2 and Figure 3), the level of tryptase fell between 5 and 30 minutes after exercise, the range being $5.9 \mu \mathrm{g} / \mathrm{L}$ (1.9-10.7) vs $5.7 \mu \mathrm{g} / \mathrm{L}$ (1.79.4), $\mathrm{P}<0.05)$. The ECP level fell significantly between pre-exercise and 30 minutes after exercise $21.8 \mu \mathrm{g} /$ $\mathrm{L}$ (6.2-62) vs $12.1 \mu \mathrm{g} / \mathrm{L}(2.2-28.4)$ ( $\mathrm{P}<0.01)$. EOS did not show any significant difference in the level between pre and post exercise.

In group three, no significant fall in the level of tryptase, ECP and EOS was observed between the pre and post exercise values.

The correlation between the variables in groups one and two was examined. In group one, tryptase correlated with EOS, pre-exercise $(\mathrm{r}=0.77 ; \mathrm{P}<0.05)$ and five minutes after exercise $(\mathrm{r}=0.77 ; \mathrm{P}<0.05)$

Tryptase also correlated with ECP five minutes after exercise $(r=0.93 ; \mathrm{P}<0.01)$. EOS correlated with ECP five minutes after exercise $(r=0.85 ; \mathrm{P}<0.05)$. EOS correlated with ECP $(\mathrm{r}=0.88 ; \mathrm{P}<0.05), 30$ minutes after exercise.

In group two, tryptase correlated with EOS pre exercise $(\mathrm{r}=0.62 ; \mathrm{P}<0.05)$ and five minutes after exercise $(\mathrm{r}=0.59 ; \mathrm{P}<0.05)$.

\section{DISCUSSION}

It has been hypothesised in an earlier study that the hyperosmolar triggering of mast cells and possibly other inflammatory cells in exercise induced asthma results in the release of bronchoconstrictor mediators(28). Lee et al.(29) suggested that physical stimulus led to mast cell degranulation and mediator release, which in turn caused bronchoconstriction.

In this study, we evaluated changes in the blood levels of tryptase, eosinophils and eosinophil cationic protein after exercise challenge in adolescents with or without EIA in Kuwait.

We observed a significant fall in the levels of tryptase in EIA and non-EIA subjects. Conflicting findings from other studies have been reported after exercise. Broide et al.(14) and Jarpour and colleagues(13) observed a fall but not significantly in tryptase level after exercise. On the other hand, other studies have reported an increase in the level of mast cell mediators after exercise(30).

We also observed in this study, a fall in the levels of ECP after exercise in both EIA and non-EIA subjects, although the fall in non-EIA subjects was more significant.

The fall observed in the levels of these mediators is difficult to explain, but since this occurred in both group one and two, it is possible that the fall reflects a reaction consequent upon the asthmatic response induced by multiple factors. Venge et al.(18) also made similar interesting observation. They found that the ECP level, after an initial rise immediately after exercise, was followed five minutes later by a fall in the level; and this fall was maintained up to 60 minutes. They could not explain the two patterns obtained, but suggested that the initial rise is a reflection of the activation of the eosinophils as consequence of the challenge. They also postulated that the fall may be dependent on the exclusive and accelerated elimination of ECP by mechanisms induced by the asthmatic reaction. They also observed that their findings on changes in ECP level after exercise challenge in EIA subjects were similar to their previous observation(31) in which subjects with asthma who reacted with a late asthma reaction (LAR) to inhalation allergen challenge had much higher serum ECP levels before challenge than subjects who did not have an LAR.

In our study we did not measure the levels of these mediators immediately after exercise. It is conceivable that an initial rise might have occurred before the subsequent fall. Similarly, Tsuda et al.(32) in their own study on children observed that ECP levels after an initial rise following exercise fell 15 minutes later in EIA positive group but not in EIA negative group. They suggested a possible involvement of eosinophils in the pathophysiology of EIA. On the contrary, Gauvreau and co-workers in a recent study, demonstrated that exercise induced bronchoconstiriction did not cause eosinophilic airway inflammation in subjects with asthma who develop airway inflammation, with the same degree as allergen induced bronchoconstriction.

Further, evidence from the study of Kivity and colleagues(20) showed that ECP in sputum did not change significantly in neither the EIA nor the nonEIA group. They however, found the amount of leukotrienes increased following exercise in patients with EIA. They concluded that the influx of eosinophils in patients who develop EIA can be partially explained by the leukotrienes in the airway of these patients, Makker and colleagues(34) had demonstrated the protective effect of inhaled leukotrienes receptor antagonist against EIA.

Our findings showed similarities to some of the earlier studies(10,23,32-33). Depletion of the mediators may be an important factor in the fall observed in the level of these mediators.

Some authors $(35,36)$ have suggested that a depletion of chemical mediators capable of inducing airway smooth muscle contraction occurs in response to exercise and renders a patient refractory to repeated challenge. Anderson(37) has shown that the existence of a refractory period to EIA in some patients which is unexplained by respiratory heat loss, suggests that the airway response to repeated challenge is modified by other factors. She concluded that multiple casual factors are operating in EIA in light of studies on refractory period, mediator release and inhibiting effects of some pharmacological agents. Bronchoconstriction in response to cooling and drying of the airway mucosa may occur either reflexly by stimulation of airway receptors or by direct action of mediators on airway smooth muscle. 
There was no significant change in $\mathrm{FEV}_{1}$, especially in group one after exercise. This finding may probably be due to the long duration of time, since initial diagnosis, that these subjects had been exposed to maintenance drug therapy. It is also possible that depletion of mediators, rendering the subjects to become refractory, might have occurred.

The suggestion of mediator release and subsequent depletion in EIA has been largely based on the observation that sodium cromoglycate inhibits EIA in the majority of patients. The only direct evidence of depletion in mediators with repeated exercise comes from a study of Anderson and colleagues $(3,8)$ which demonstrated a reduction in the release of histamine into arterial plasma and simultaneous reduction in EIA with repeated challenge.

In conclusion, although, this study has shown a fall in the levels of ECP and tryptase after exercise challenge, further studies will be required, using a large number of subjects, to determine the role of mediator depletion in the refractory state, particularly as controversies still exist as to whether mediators are released in significant quantities at all during exercise. The results of studies so far on the refractory period, mediator release and pharmacological agents suggest that multiple causal factors occur in response to the loss of heat and water from the airways during exercise.

\section{ACKNOWLEDGEMENTS}

To Dr. Ali Attia of the Cardiology Unit of Mubarak Hospital for conducting the exercise test on all the subjectsand Dr. J.M. Ramadan and his chief technician, Mr. G. Telahoun of the Department of Physiology for providing us with the data on the patients with confimed exercise-induced asthma. We also thank Mrs. Elizabeth Philip for assisting with the immuno assays and Mrs. Ajitha Suresh for help with data analysis.

\section{REFERENCES}

1. Anderson, S. D., Silverman, M., Godfrey, S., Konig, P. Exercise-induced asthma, a review. Brit. J. Dis. Chest. 1975; 69:1-39.

2. Freed, A. N. Models and mechanisms of exercise-induced asthma. Eur. Respir. J. 1995; 8:1770-1785.

3. Tan, R. A, Spector, S. L. Exercise-induced asthma. Sports med. 1998; 25:1-6.

4. Godfrey, S., Konig, P. Inhibition of exercise-induced asthma by different pharmacological pathways. Thorax. 1976; 31:137-143.

5. Patel, K. R. Calcium antagonists in exercise-induced asthma. Brit. Med. J. 1981; 282:932-933.

6. Anderson, S. D, Seale, P., Ferris, L., Schoeffel, R., Lindsay, D. A. Evaluation of pharmacotherapy in exercise-induced asthma. J. Allergy. Clin. Immunol. 1979; 64: 612-624.

7. Silverman, M., Andrea, T. Time course effect of disodium cromoglycate on exercise induced asthma. Arch. Dis. Child 1972; 47:419-422.

8. Barnes, P. J, Brown, M. J. Venous plasma histamine in exercise and hyperventilation induced asthma in man. Clin. Immunol. 1981; 61:159-162.

9. Lee, T. H, Brown, M. J, Nagy, L., Causon, R., Walpjort, M. J., Kay,. A. B. Exercise induced release of histamine and neutrophil chemotactic factor in atopic asthmatics. J. Allergy Clin. Immunol. 1982; 70:73-83.

10. Deal, E. C., Jr, Wasserman, S. I, Soter, N. A, Ingram, R. H., McFadden, E. R. Evaluation of role played by mediators of immediate hypersensitivity in exercise-induced asthma. $J$. Clin. Invest. 1980; 65:659-665.

11. Hartley, J. P. R., Norgrady, S. G. Effect of an inhaled antihistamine on exercise-induced asthma. Thorax. 1980; 35:593-594.

12. Togias, A. G, Naclerio, R. M., Proud, D., et al. Nasal challenge with cold, dry air results in release of inflammatory mediators, possible mast cell involvement. J. Clin. Invest. 1985; 76:1375-1381.

13. Jarjour, N. N., Calhoun, W. J., Stevens, C. A., Salisbury, S. M. Exercise-induced asthma is not associated with mast cell activation or airway inflammation. J. Allergy Clin. Immunol. 1992; 89:60-68.

14. Broide, D. H., Eisman, S., Ramdell, J. W., et al. Airways level of mast cell derived mediators in exercise-induced asthma. Am. Rev. Respir. Dis. 1990; 141:563-568.

15. O'Sullivan, S., Roquet, A., Dahlen, B., et al. Evidence for mast cell degranulation during exercise-induced bronchoconstriction. Eur. Respir J. 1998; 12:345-350.

16. Durham, S. R; Loegering, D. A, Dunnette, S., Gleich, G. J., Kay, A. B. Blood eosinophils and eosinophil-derived proteins in allergic asthma. J. Allergy Clin. Immunol. 1989; 84: $931-936$.

17. Sabina, R., Laowhagen, O., Venge, P. The effect of immunotherapy on hyperresponsiveness and eosinophil cationic protein in allergic patients. J. Allergy. Clin. Immunol. 1988; 82:470-481.

18. Venge, P., Henriksen, J., Dahl, R. Eosinophils in exerciseinduced asthma. J. Allergy Clin. Immunol. 1991; 88:699-704.

19 Yoshikawa, T., Shoji, S., Fuji, T., et al. Severity of exerciseinduced bronchoconstriction is related to airway eosinophilic inflammation in patients with asthma. Eur. Respair. J. 1998; 12:879-884.

20. Kivity, S., Argaman, A., Onn, A., Shwartz, Y., Man, A., Grief, J. and Fireman, E. Eosinophil influx into the airways in patients with exercise-induced asthma. Resp. Med. 2000; 94:1200-1205.

21. Koh, Y. I.; and Choi, I. S. Blood eosinophil counts for the prediction of the severity of exercise-induced bronchospasm in asthma. Resp. Med. 2002; 96:120-125.

22. Gauvreau, G. M, Ronnen, G. M., Watson, R. M., O'Byrne, P. M. Exercise-induced bronchoconstriction does not cause eosinophilic airway inflammation or airway hyperresponsiveness in subjects with asthrna. Arn. J. Respir. Crit. Care. Med. 2000; 162:1302-1307.

23. Onadeko, B. O., Khadadah, M. E., Mustafa, H. T. S., et al. Serum eosinophil cationic protein as a predictor of disease activity in acute and chronic asthma. East. Afr. Med. J. 1999; 76:524-529.

24. Marouf, R., Khadadah, M. E, Onadeko, B. O, et al. The effect of corticosteroid therapy on blood eosinophils and eosinophil cationic protein in patients with acute and chronic asthma. Jour. of Asthma. 1999; 36:555-564.

25. American Thoracic Society. Standardisation of spirometry; 1994 update. Amer. J. Respir. Crit. Care. Med. 1995; 152:1107-1136.

26. American Thoracic Society. Guidelines for methaeholine and exercise challenge testing-1999. Amer. J. Respir. Crit. Care. Med. 2000; 161:309-329.

27. Lewis, S. M., Bain, B. J., Bates, I. in Dacie and Lewis. 
Practical Haemotology. Churchill Livingstone, 9th edition. 2001, P. 25.

28. Togias, A. G., Proud, D., Lichtenstein, L. M., et al. The osmolality of nasal secretions increases in the inflammatory response to inhalation of cold, dry air. Am. Rev. Respir. Dis. 1988; 137: 625-629.

29. Lee, T. H., Nagakura, T., Papageorgiou, N., Cromwell, O., Likura, Y., Kay, A. B. Mediators in exercise-induced asthma. J. Allergy. Clin. Immunology. 1984; 73:634-639.

30. Casale, T. B., Wood, D., Richerson, H. B, et al. Direct evidence of a role for mast cells in the pathogenesis of antigen-induced bronchoconstriction. J. Clin. Invest. 1987; 80:1507-1511.

31. Venge, P., Dahl, R. Are blood eosinophil number and activity important for the development of the late asthmatic reaction after allergen challenge? Eur. Respir. J. 1982; (suppl. 6) 2:430S-434S.

32. Tsuda, H., Tsuda, A., Ito, M., et al. Role of eosinophils and catecholamines in pathophysiology of exercise-induced asthma; Paediat. Allergy. Immunol. 1993; 43:221-225.

33. Belcher, N. G., Murdoch, R., Dalton, N., et al. Circualting concentrations of histamine, neutrophil chemotactic activity and catecholamines during the refractory period in exerciseinduced asthma. J. Allergy. Clin. Immunol. 1988; 81:100110.

34. Makker, H. K., Lau, L. C., Thomson, H. W., Binks, S. M., Holgate, S, T. The protective effect of inhaled leukotriene D4 receptor antagonist ICI 204, 219 against exerciseinduced asthma. Am. Rev. Respir. Dis. 1993; 147:14131418.

35. Edmunds, A. T., Tooley, M., Godfrey, S. The refractory period after exercise induced asthma: its duration and relation to the severity of exercise. Am. Rev. Respir Dis. 1978; 117:247-254.

36. Schoeffel, R. E., Anderson, S. D., Gillam, I., Lindsay, D. A. Multiple exercise and histamine challenge in asthmatic patients. Thorax 1980; 35:164-170.

37. Anderson, S. D. Recent advances in the understanding of exercise-induced asthma. Eur. J. Respir. Dis. 1983; (suppl. 128) 64:225-236.

38. Anderson, S. D., Bye, P. T. P., Schoeffel, R. E, et al. Arterial plasma histamine levels at rest, and during and after exercise in patients with asthma: effects of terbutaline aerosol. Thorax. 1981; 36:296-267. 